Journal of Teacher Education for Sustainability, vol. 12, no. 1, pp. 51-65, 2010

\title{
TEACHERS AS RESEARCHERS: BRINGING TEACHERS' VOICE TO THE EDUCATIONAL LANDSCAPE
}

\author{
Dzintra Iliško, Svetlana Ignatjeva and Ilona Mičule \\ Daugavpils University, Latvia
}

\begin{abstract}
There are a number of studies addressing the possible benefits of teachers being engaged in research, but there is little research that explores what teachers themselves think about their role as researchers and how they evaluate themselves as researchers. The aim of this study is to present a small scale investigation into teachers' self-perception of doing research in mainstream schools. By doing research, teachers express their voice; teachers' voice is an expression of their frames of reference. This is also a way of making their perspective public. In Latvia, teachers do not have an active voice in the educational theory and research. This research indicates that research initiated by teachers provides a framework for strengthening teachers'voice. The research data present an analysis of teachers' self-evaluation of their research competency, ability to organize their own research activity and that of their children. The study highlights the factors that determine teachers' willingness to engage in doing research, as well as their expertise to organize and motivate children's research. The data from group interviews and questionnaires show a genuine degree of agreement on a number of main issues, such as teachers' motivation in doing research, their expertise to motivate children in doing their research, as well as teachers' openness to creative and imaginative insights brought about by the primary school children in their research projects. This study highlights several significant correlations between teachers' ability to carry out their own research and their ability to engage children in a meaningful research.
\end{abstract}

Key words: research skills, creativity, teachers' voice, research environment

\section{Introduction}

Schools more often play a role of bureaucratic institutions, thus weakening the voice of teachers and making them perform the role of technicians who merely follow the state mandatory standards. Iliško \& Kravale (2007) wrote that "the most common features of education are: high stress among teachers, return to a didactic teaching, a decline in teacher-led innovations and teachers' unwillingness to make a difference” (p. 260). The majority of teachers is trained in an authoritarian tradition and expects the teaching to be constant and predictable. In order to respond to the diverse needs of their children 
and to address current educational challenges, teachers need to make use of their most powerful ways of knowing - their subjectivities and intuitions and to validate such insights in children's research. Teachers must be able to understand the unique and particular aspects of their practice and their classrooms in order to make a difference in the lives of their children and their particular experience.

The key issue is teachers' voice. Teacher's voice is viewed as a teacher's ability to define their educational philosophy, as well as to act accordingly towards implementing sustainable changes in the educational realm (Kincheloe, 2003). One of the ways of initiating educational changes in the school environment is through doing action research. Teacher initiated research is one of the possibilities that offers a way beyond alienation. Teachers' participation in educational realm implies a possibility for teachers' voice to be heard. According to Dewey (1916), teachers need to have a voice in the formulation of educational policy.

Most teachers believe that teaching and research are two different spheres of work. Research is about formulating deep questions, examining phenomena and interpreting understandings, while teaching is about teaching others. The boundaries between these fields begin to blur for some teachers and in some school settings. Still, the distinction between these two fields of work is a part of reality for most teachers. Hargreaves (1995) argues that there is a huge gap between researchers and practitioners. Researchers determine the agenda for educational research, but teachers assure that research has little relevance to classroom practice. This separation between teaching and researching is based on a view that both spheres of work have different aims. Research is supposed to produce new knowledge in most cases, while teachers are viewed merely as a tool to implement it. In Latvia, researchers usually work in one setting while teachers work in another setting. However, many researchers have suggested that teachers can act as true professionals only when they make active attempts to link and apply educational theory to their practice.

Literature has produced important insights on teacher's engagement with the research and the relations between teaching and researching. Several studies indicate: 1) teaching and researching are the same thing; 2) teachers have to support their own teaching by doing research in order to support learning of their students; 3 ) teaching and researching has many benefits, though this work is very hard (Brookfield, 1995; Schon, 1983; CochranSmith \& Lytle, 1993; Lytle \& Cochran-Smith, 1992; McFearland \& Stansell, 1993; Etherington, 2006; Kincheloe, 2003). Some teachers successfully combine both activities, particularly those who hold a master's degree or actively participate in various international projects.

\section{Research as a tool to address education for sustainable development}

Education for sustainable development is an approach to education that is oriented towards helping teachers' to arrive at a better understanding of actions and how those actions can play a role in addressing the problems that future brings about. Education for sustainable development requires the reorientation of educational policy, curriculum and practices inherent to sustainability. Rethinking and revisioning education includes focusing on the development of teachers' knowledge, skills and perspectives related to sustainability. This implies a revision of the traditional approaches to teaching. These include skills for innovative and critical thinking, cooperation skills, decision-making, problem-solving and other important skills that can be well developed by encouraging teachers to engage in action research. 


\section{Why doing teacher-initiated research?}

The term teacher-researcher characterizes a professional who is reflective and motivated to identify and address problems in his/her praxis. The concept of teacher as researcher has been of interest to various scholars (Cochran-Smith \& Lytle, 1993; McFearland \& Stansell, 1993; Etherington, 2006; Kincheloe, 2003). Teachers as researchers demonstrate high professionalism as 'reflective practitioners' (Brookfield, 1995; Schon, 1983; Stenhouse, 1981). Kincheloe (2003) describes teachers as "self-directed agents, sophisticated thinkers in a never-static, ambiguous context" (p. 40) who engage in "a metadialogue and constant conversation with one's self" (p. 69).

Cochran-Smith \& Lytle (1993) define teachers' research as systematic inquiry carried out by teachers. This understanding is consistent with Goswami \& Stillman's (1987) idea that every lesson should be an inquiry for a teacher. Research requires teachers to engage in the process of questioning, planning, acting, observing, reflecting, pre-planning. It puts the teacher at the centre of knowledge production in the professional context of the classroom. Teacher initiated research can be defined as intentional and systematic inquiry. Teacher initiated research is perceived as reflexive, ethical and practical inquiry (Stringer, 1999).

Teacher initiated research is a process of systematical, critical and reflective evaluation of educational practice and action towards adjusting the practice to maximize effectiveness (Sagor, 2000). It encourages teachers to try out new ideas, methods and materials, and to make decisions about curriculum development. Teacher initiated research is critical and reflective. Reflectivity in doing research means attentiveness to one's biases, predispositions and preferences (Schwandt, 2001).

There are several reasons why teachers engage in carrying out the research: to improve their teaching, to arrive at a better understanding of their actions and teaching, as well as to regain their voice and to make a difference. One of the reasons why teachers engage in doing research is to improve the practice by arriving at a better understanding of their practice. This leads teachers to work towards a sustainable change in the context in which the practice occurs (Stringer, 1999). The other reason why teachers are doing research is to enrich their understanding of what is going on in the classroom. The positive effects of conducting research in the classroom are tremendous: teachers build their own theory of teaching; they act as curriculum designers and make informed decisions in their classrooms. Teacher initiated research can be seen as a tool in developing teachers' capacity for making autonomous and professional judgments and decisions about their classroom practice. Teachers gain more confidence to improve teaching. Teachers act as curriculum designers and adjust their practice based on their conclusions derived from the study. Research helps teachers to make informed decisions about their classroom practice.

\section{The power of teacher's voice: Constructivist vision}

Several studies suggest (Kincheloe, 2003; Apple, 1999; Chattin-McNichols \& Loeffler, 1989) that the teachers who operate at a constructivist level are more tolerant towards the original questions posed by children. Constructivism underlines the assumption that knowledge is not transmitted from one person to another, but is constructed. Thus, teachers become more flexible and employ a wider repertoire of teaching models. While 
operating at this level, teachers are able to see the discrepancies between the surface approaches and the deeper reality. Such a position allows teachers to carry out research as a tool in overcoming bureaucratic definitions of their role. This empowers teachers to construct new ways of thinking about teaching and teacher education. After involving themselves in conducting research with the purpose of improving their educational practice, teachers gain new and better ways of seeing their classroom practice and transcend the empty rhetoric of educational talk. As numerous constructivists (Linn, 1987; Harris \& Graham, 1994) believe, teachers who take initiative in doing action research become active decision makers about what concerns their work and see new perspectives in the context in which they operate. They believe that teaching can be structured in a personal and meaningful way that must be constantly developed. Such a view allows teachers to re-conceptualize their understanding of teaching, as well as their role. Teachers' autonomy begins with the construction of a system of meaning. Here feminist theory, liberation theology, Deweyan educational theory serve as a starting point for teachers' ongoing construction and reconstruction of meaning. Freire (1972) believes that both teachers and students need to be actively involved in educational process as decision makers.

Constructivist learning is inspired by theories of learning that underline that learning is an active process where learners and teachers are actively constructing mental models and theories of the world around them. Constructivism is based on epistemological assumptions that knowledge is constructed by a knower who actively interprets experience, that is, makes sense of it in terms of what the learner already knows. Therefore, as Koutselini (2008) argues, instead of laying the main emphasis in teacher training courses on developing teachers' skills and competencies where teaching is viewed as a set of measurable skills and routine techniques, teachers should be encouraged to accept the role of a critical and reflective researcher who experiences teaching as praxis, "a unique experience that is influenced by teachers' reflective judgments, moral assumptions and justifications" (p. 35), where teachers have their own voice and where they construct their meaning. By regaining their voice, teachers can become open to innovative aspects in children's inquiries.

Primary school children live in a constant state of curiosity. For them inquiry comes from what is interesting in the world. Therefore, children pose deep and meaningful questions. Children's individual structures of meaning allow alternative perspectives to the world to be expressed that provide alternative ways of meaning creation about the world. It is a matter of teacher's professionalism to bring multiple knowledge systems to a topic, by offering a space for different questions to be raised about the topic from the perspectives that each system offers. Such a learning environment allows learners to explore and create new ideas and to shape what they are learning as they examine the topic through their own personal experiences and different knowledge systems. In the primary school setting, inquiry is not only dry, analytical process for doing research. Instead, it should be seen as a deeply passionate, mysterious, exciting and creative process. Inquiry should bring a sense of wonder about the surrounding environment and nature, since inquiry is "a way of travelling along the web of connections, to explore the myriad relationship that connect us to the world and ultimately make up who we are"(Montuori, 2008, p. 18). Such an understanding allows teachers to tolerate ambiguity in children's questions and inquiries. This also brings teachers closer to their authentic selves and the expression of voice that brings along "powerful and life-affirming feeling" (Montuori, 2008, p. 21). 


\section{Research methodology}

The current study reflects the analysis of data gained both by qualitative and quantitative research methods. This research objective is not merely to validate the statistical relationships of variables, but to understand and to preserve the cohesiveness of the phenomena studied. Attention was paid to both portraying patterns and discovering the causes that prevent teachers from being active builders of their everyday reality in the classroom setting and how their agency influences children's agency to undertake research.

Group interviews with teachers allowed us to gain deeper insights of the teachers' understanding of their role as researchers, as well as to discover the obstacles that hinder them from becoming critical and reflective researchers. While conducting group interviews in four regions of Latvia in groups of 15 to 25 teachers $(\mathrm{N}=84)$, particular attention was paid to the social, political and ideological contexts in which teachers work, since these contexts influence their perception of themselves as researchers. Group interviews allowed working collaboratively with research participants and presenting a value of narrative knowledge, as well as sharing 'the lived experiences' of teachers that inform the research and disclose conceptual themes and depth of teachers' interpretations.

Teachers' narratives portray how they experience their position as researchers. Embedded in teacher stories are teachers' feelings, thoughts and attitudes that helped the authors to better understand how teachers make sense of what they are doing. As several authors suggest, narrative analysis treat stories as "actually constituting the reality of the narrator" (Bruner, 1992; Ochberg, 1994). While analysing the teachers' stories, the authors paid particular attention to the way the teachers frame issues - to patterns, themes, dilemmas, key phrases that seemed to hold multiple meanings. As Husserl (1970) suggests, participatory epistemology focuses on subjective and active engagement with the world and phenomena, and the only way of knowing things is through our subjective knowing. All teachers who participated in group interviews were full time teachers.

All teachers $(\mathrm{N}=123)$ who participated in this study were also asked to fill in a questionnaire on a voluntarily basis; all teachers were given a clear instruction on how to complete the survey. All data of this survey was collected by the authors. Items on the demographic indicators summarized information about the teachers' age, gender and experience in doing research (writing a scientific report, a bachelor's or master's thesis). Teachers needed to indicate if they had any previous experience in presenting their research data within the school community, at the local conferences or even international reunions. The aim of the questionnaire was intended to discover the main reasons why teachers are doing research (professional growth, pursuing one's career or as a job requirement). The teachers involved in this study are mainly kindergarten and primary school teachers. The other part of the questionnaire was designed to indentify the teacher's self-evaluation of their competency to organize research work for children, their creativity in organizing and doing research, as well as their skills in organizing research. The authors aimed at determining significant correlations among these factors.

For the statistical analysis of data, the authors chose SPSS program (Statistical Package for the Social Sciences). Reliability measures were used to explore the existence of underlying factors representing the various concepts under study, namely, teachers' engagement with the research, their ability to organize their research and the research of the children, ability to work with creative and imaginative insights brought in by the children. Triangulation procedures and discourse analysis during the meetings revealed teachers' beliefs and preconceptions of the role of the teacher-researcher. The insider status of the authors 
of this research helped them to clarify the understanding of personalities, interactions and responses of teachers during the group interviews. The employed method might have obscured the authors' understandings. On the one hand, the authors' insider position was a benefit, because the authors were aware of the struggles the teachers were talking about, but, on the other hand, the authors could have assumed things about the teachers. The authors made every effort to structure the study so that it ensured stronger validity.

\section{Research participants}

The research participants were primary school and kindergarten teachers who are undergoing in-service teacher training in different in-service programmes $(\mathrm{N}=123)$. Out of all respondents, $23 \%$ claimed to have no research experience, $55 \%$ had an experience of writing a research paper (Mean=3.60), 11\% of teachers are holding a bachelor's degree and $9 \%$ are graduates of master's degree programmes. $54 \%$ of all participants admitted that they had no experience in presenting their research findings at the level of conferences, while $46 \%$ had had an experience in presenting their research findings at local and regional scale conferences.

\section{Research findings}

One of the aims of the questionnaire was to discover the motivation behind the teachers' participation in educational research. One may find different motivation among teachers for doing research. They were provided with several options to select from and were asked to formulate their own reasons for doing research. Among the reasons suggested was promotion, professional growth, administrative requirement and a passion to make a difference in their classroom setting. The questionnaire helped to find out the motivation of research participants to undertake research.

The highest motivation for doing one's own educational research was among the older teachers ( 56 years of age and older), the lowest motivation of doing research was among younger teachers (25 years) (Mean=4.15). They consider themselves confident and equipped with the latest knowledge after graduating from higher educational establishments. The main motivation why they engage in an educational research is pressure from the administration (Mean=2.50). Their personal motivation for doing educational research is quite low $($ Mean=3.78). The main motivation for the older teachers is their personal growth. The kindergarten teachers' motivation for doing educational research is mainly determined by administrative requirements, while primary school teachers have demonstrated professional and personal motivation.

Self-evaluation of the teachers' skills to organize research environment for primary school children indicates that the highest indicator is among the younger teachers, who have just graduated (Mean=3.5), as well as among the most experienced teachers (56 years and older) (Mean=3.5), while the lowest indicator was in the age group from 2635. These teachers feel quite confident with the routine and their preferred style of teaching and do not intend to change much. There is a correlation between the teachers' educational level and their skills to engage children in doing research. The teachers who are holders of a master's degree evaluated their skills higher in organizing a research environment for children than the teachers who only studied in the bachelor's degree programmes or who are the graduates of these programmes. 
With the purpose of measuring the teachers' competence of organizing children's research work, the authors have identified twenty four indicators. Principal Component Analysis (PCA) with varimax rotation of questionnaire data helped the authors to identify three major factors of teacher's skills to engage children in doing research:

- teachers' skills to manage their own inquiry (F1).

- ability to work with gifted children or children who pursue innovative and creative ideas for their research (F2).

- ability to organize children's research activity (F3).

Items, their loadings and appropriate reliability coefficients (Alpha) are shown in Table 1.

Table 1. Means, standard deviations, reliabilities and principal component analysis results of the teachers' skills to engage the children in doing research

\begin{tabular}{|c|c|c|c|c|c|}
\hline Items & $M$ & $S D$ & F1 & $F 2$ & F3 \\
\hline 1 & 2 & 3 & 4 & 5 & 6 \\
\hline $\begin{array}{l}\text { Children's ability to see the beautiful in } \\
\text { the surrounding }\end{array}$ & 3.96 & 0.71 & 0.77 & & \\
\hline Sensitivity towards the fantasy world of the children & 3.87 & 0.79 & 0.76 & & \\
\hline Openness to innovative ideas of the children & 3.60 & 0.79 & 0.74 & & \\
\hline $\begin{array}{l}\text { Openness to innovative ideas of the children about } \\
\text { the surrounding world }\end{array}$ & 3.70 & 0.79 & 0.73 & & \\
\hline $\begin{array}{l}\text { Openness to diverse and innovative ideas to } \\
\text { the offered problems }\end{array}$ & 3.74 & 0.76 & 0.73 & & \\
\hline Tolerance towards the sense of humour of the children & 4.01 & 0.71 & 0.73 & & \\
\hline Tolerance towards the independent ideas of the children & 3.84 & 0.74 & 0.73 & & \\
\hline Tolerating the creative chaos of the children & 3.59 & 0.72 & 0.62 & & \\
\hline Tolerating the critique from the children & 3.78 & 0.72 & 0.50 & & \\
\hline $\begin{array}{l}\text { Helping the children with structuring the information } \\
\text { and planning their research }\end{array}$ & 3.29 & 0.73 & & 0.79 & \\
\hline Suggesting the children interesting themes for research & 3.14 & 0.73 & & 0.74 & \\
\hline $\begin{array}{l}\text { Suggesting the topics of research by fostering } \\
\text { intersubjective integration }\end{array}$ & 3.13 & 0.82 & & 0.74 & \\
\hline Mentoring the children in conducting their research & 3.59 & 0.78 & & 0.65 & \\
\hline Evaluating the inquiry projects done by the children & 3.13 & 0.89 & & 0.65 & \\
\hline $\begin{array}{l}\text { Evaluating the children's need for information about } \\
\text { the issue of the study }\end{array}$ & 3.46 & 0.70 & & 0.60 & \\
\hline $\begin{array}{l}\text { Mentoring the children in the process of gathering } \\
\text { information }\end{array}$ & 3.60 & 0.67 & & 0.56 & \\
\hline Evaluating the ideas and results of the young scientists & 3.20 & 0.89 & & 0.46 & \\
\hline $\begin{array}{l}\text { Teaching the children about the ethical aspects of } \\
\text { conducting research }\end{array}$ & 3.59 & 0.76 & & & 0.41 \\
\hline $\begin{array}{l}\text { Encouraging the young scientists to participate in } \\
\text { presenting their research }\end{array}$ & 3.41 & 0.73 & & & 0.78 \\
\hline
\end{tabular}


Sequel to Table 1.

\begin{tabular}{|c|c|c|c|c|c|}
\hline 1 & 2 & 3 & 4 & 5 & 6 \\
\hline Organizing team work while conducting research & 3.62 & 0.77 & & & 0.72 \\
\hline Organizing a presentation of the research work & 3.66 & 0.81 & & & 0.71 \\
\hline Organizing a discussion about the research issue & 3.17 & 0.66 & & & 0.63 \\
\hline Motivating the children to carry out their research & 3.82 & 0.74 & & & 0.60 \\
\hline $\begin{array}{l}\text { Advertising the research work of the children to } \\
\text { the colleagues }\end{array}$ & 3.66 & 0.66 & & & 0.45 \\
\hline
\end{tabular}

$\begin{array}{rccc}\text { \% of Variance } & 24.7 & 18 & 15.21 \\ \text { Alpha } & 0.91 & 0.9 & 0.87\end{array}$

To measure the teachers' IT competence, the authors have identified twenty three indicators that allowed the authors to evaluate the teachers' IT competence in a five point scale in doing diverse measurement activities in processing the data both with the use of technologies and with paper and pencil. As a result of the use of Principal Component Analysis (PCA), the authors have identified three factors that were classified in the folowing way:

- teachers' competency to use IT for the purpose to search, to process, to analyse and to present the information (IK1);

- teachers' competency to process information using paper and pencil (IK2);

- teachers' skills of communication with colleagues in virtual environment (IK3).

Items and their loadings with appropriate reliability coefficients (Alpha) can be seen in Table 2.

Table 2. Means, standard deviations, reliabilities and principal component analysis results of primary school teachers' IT competence.

\begin{tabular}{lccccc}
\hline \multicolumn{1}{c}{ Items } & M & SD & IK1 & IK2 & IK3 \\
\hline \multicolumn{1}{c}{1} & 2 & 3 & 4 & 5 & 6 \\
\hline $\begin{array}{l}\text { Preparing materials for the educational process by } \\
\text { using a computer }\end{array}$ & 3.46 & 1.31 & 0.84 & & \\
$\begin{array}{l}\text { The use of information technologies for data } \\
\text { processing }\end{array}$ & 3.27 & 1.29 & 0.82 & & \\
Preparation and documentation in electronic format & 3.67 & 1.29 & 0.81 & \\
$\begin{array}{l}\text { Presenting charts and diagrams using a computer } \\
\text { Searching information on the Internet }\end{array}$ & 3.12 & 1.30 & 0.79 & \\
$\begin{array}{l}\text { Preparing a presentation about the issue of the study } \\
\text { Preparing and presentating the issue }\end{array}$ & 3.88 & 1.08 & 0.77 & \\
$\begin{array}{l}\text { Searching information in electronic catalogues } \\
\text { and other sources }\end{array}$ & 3.24 & 1.19 & 0.76 & \\
$\begin{array}{l}\text { Processing quantitative data with the help of } \\
\text { SPSS, Excel }\end{array}$ & 2.89 & 1.28 & 0.70 & & \\
Exchanging information with the colleagues by & 2.77 & 1.40 & 0.56 & & \\
using e-mails & & & & & \\
\hline $\begin{array}{l}\text { Processing quantitative data by using paper and } \\
\text { pencil }\end{array}$ & 4.24 & 0.80 & & 0.82 & \\
\hline
\end{tabular}


Sequel to Table 2.

\begin{tabular}{|c|c|c|c|c|c|}
\hline 1 & 2 & 3 & 4 & 5 & 6 \\
\hline $\begin{array}{l}\text { Processing information by using analytic data } \\
\text { processing methods }\end{array}$ & 4.09 & 0.84 & & 0.78 & \\
\hline $\begin{array}{l}\text { Designing methodical documentation by using } \\
\text { paper and pencil }\end{array}$ & 4.21 & 0.82 & & 0.78 & \\
\hline $\begin{array}{l}\text { Searching information in catalogues, dictionaries } \\
\text { and print }\end{array}$ & 4.20 & 0.80 & & 0.75 & \\
\hline $\begin{array}{l}\text { Searching necessary sources of information about } \\
\text { the issue of the study }\end{array}$ & 4.20 & 0.82 & & 0.69 & \\
\hline Preparing necessary aids in the educational process & 4.33 & 0.87 & & 0.68 & \\
\hline $\begin{array}{l}\text { Preparing and presenting research findings } \\
\text { without the use of computer }\end{array}$ & 3.83 & 0.94 & & 0.68 & \\
\hline Presenting findings in charts and diagrams & 3.85 & 1.06 & & 0.66 & \\
\hline $\begin{array}{l}\text { Using print sources for the purpose of the research } \\
\text { in one's subject area }\end{array}$ & 4.01 & 0.98 & & 0.57 & \\
\hline Participation in discussions with colleagues & 3.67 & 1.03 & & & 0.52 \\
\hline Participation in internet professional networks & 1.36 & 0.84 & & & 0.73 \\
\hline Participation in internet conferences, forums & 1.44 & 0.86 & & & 0.67 \\
\hline Participation in professional unions & 2.76 & 1.70 & & & 0.62 \\
\hline & & $\begin{array}{l}\text { ince } \\
\text { pha }\end{array}$ & $\begin{array}{l}27.5 \\
0.94\end{array}$ & $\begin{array}{l}23 \\
0.9\end{array}$ & $\begin{array}{c}10.88 \\
0.68\end{array}$ \\
\hline
\end{tabular}

There are several significant correlations that can be identified in the study: the correlation between the teachers' creativity and their skills to organize their own research $(r=0.620)$; the correlation between the teachers' skills to use IT and their ability to organize their research $(r=0.489)$. The age is also an essential factor for the teachers' ability to work with gifted children $(r=0.215)$. The teachers' ability to do their own research influences their ability and skills to organize children's research activity $(r=0.206)$. This allows the authors to conclude that such factors as teachers' experience in conducting their own research, their experience of work at school (age), as well as the competency of using the IT technologies in doing research are significant factors in teachers' expertise organizing children's research activities. There is a clear tendency that indicates that the teachers who have a capacity, ability and skills to do their own educational research as a rule have an experience in writing a research paper (Mean=3.15), bachelor's (Mean=3.20) or master's thesis (Mean=3.14). They also have higher personal motivation in doing research (Mean=3.52).

Cluster analysis helped the authors to identify three groups of teachers: 1 ) teachers who can do their educational research have creativity and good skills in organizing research environment for children $(66 \%) ; 2$ ) teachers who have low motivation and skills to carry out their own research, do not show creativity towards their work and have low skills to use IT $(15 \%) ; 3)$ the group of teachers who have skills of work with gifted children, but have low motivation and skills to do their own research $(19 \%)$. The questionnaire designed for this study also aimed to learn about the teacher's ability to encourage and to be open to diverse forms of creativity in primary school children's 
inquiry, as well as to use imagination, creativity and openness to diverse perspectives in their own inquiries. The study indicates that the teachers are quite open to original ideas proposed by the children. Though, the majority of the teachers give preference to pursue children's research questions that have a clear answer. There is a correlation between the teachers' ability in doing their own educational research and their openness to creative impulses in children research, and originality of their ideas $(r=0.232)$.

Inquiry allows assessing the teachers' openness to creative insights brought about by children. Through creating new ideas, teachers also strengthen their voice. This creative attitude leads teachers to create their own meaning. This passion and openness to diverse possibilities and options in teacher research brings teachers to the understanding that they can make a difference, and that this difference will make a difference (Freire, 1972). Some teachers reported their readiness to support children's explorations of individual topics in projects where children choose to investigate the issue of personal interest. This requires teachers' educational imagination for looking at themselves from a different perspective, being aware of the multiple ways of how they can interpret their lives. Educational imagination is also about not accepting the things as they are, but about experimenting and exploring possibilities, reinventing the self and the world. This is teacher's ability to try out something different and be open to new perspectives and experiences. There is a strong correlation between the teachers' creativity in pursuing their own inquiry, their ability to allow different perspectives to emerge and openness to originality in children's research $(\mathrm{r}=0.186)$. Those teachers dare to allow children to explore deeper questions, such as What makes Peter a good friend? or Does God exist?

\section{Pros and cons of doing research: Teachers' reports}

The group interviews with teachers allowed identifying several obstacles that prevent the teachers from doing research: a lack of sufficient time for the research, rigid state requirements preventing the teachers from practicing creativity, overloaded schedule and a disbelief in their power to make a difference. The context of top-down, unquestionable standards and anti-intellectual culture of schools are preventing the teachers from becoming active researchers and pursuing research with their children.

The analysis of qualitative data points to clear signs of the teachers' alienation from the current educational system. In the group interviews, the teachers pointed out that few in schools respect them; few value their voices and their knowledge. Schools are becoming venues of ideological indoctrination while reducing the teachers to deliverers of homogenized information, thus, leaving the economic, social and psychological wellbeing of children a minor issue. Operating in such an environment, the teachers often find themselves discouraged, unable to find meaningful answers to essential questions concerning teaching. This forces the teachers to direct their attention to isolated skills and to render the entire process inauthentic, inert and reductionist.

The research data indicate that critical teachers understand the centrality of power in their lives, knowledge production, curriculum development and teaching. These teachers raise questions of larger purpose in relation to their everyday practice. These teachers consider themselves as researchers who critically reflect on their professional needs and current understandings. These teachers pursue existential questions with their children, such as Why are people cruel? What happens with the soul of the frog when it dies?, What is happiness? 
One of the teachers commented, "There are no right questions and there are no right answers to those questions." This teacher believes that children can become authorities for themselves when they construct their knowledge about their own questions. Teachers help to redirect children in their quest from what others might see as right to a search what is right for them. Unfortunately, these are few cases mentioned that can be so liberating for children's inquiries. In the majority of cases mentioned, the questions that dominate the classrooms in primary schools in Latvia emphasise yes and no responses. These are mainly questions related to nature and social sciences that have a clear answer and that can be answered in a positivist research tradition.

The research findings prompted by Pipere (2007) and Grišane (2007) support the evidence gained in this study. One of the main external factors that keep teachers away from engaging in educational research is time. As the teachers admitted themselves, it is quite difficult to find enough time to carry out research, to collect data and to find time to reflect and analyse data. The comment expressed by one the participants of the study well illustrates the situation.

Teachers are so overwhelmed with the paper work that there is hardly any time left for doing research. Teachers should be free from everyday problems, so that these problems do not overshadow the aim of being a researcher.

The other significant factor that prevents teachers from engaging in professional inquiry is workload. Teachers' professional schedules are quite overloaded and do not allow teachers to experience the same autonomy as researchers. As teachers commented, these are government and school authorities who set the curriculum, select materials, decide how the job has to be done and evaluate it. Besides, teachers' work includes a wider range of responsibilities than merely conducting classes. High work demands and reality of full time teaching affect teachers' decision not to do research. On the other hand, high demands put on teachers require them to engage in doing research to some degree to remain knowledgeable. One of the teachers commented:

Research is a part of our everyday routine. Now we are dealing with children
who are different from those we have taught several years ago. We need
new approaches to deal with them; therefore this makes me constantly search
an answer in the internet or in the sources in psychology. My work is an
ongoing learning experience and a research of some kind.

The teachers are forced to attend courses on a regular basis and do some scientific reading related to the field of their professional work. To meet high professional standards in teaching also means knowing the latest research in the discipline to address new undefined phenomena and contexts. Teachers often have to act on the unknown in terms of what they know. One of the obstacles mentioned by the teachers is a lack of cooperation with parents. The teachers reported that in most cases parents are very supportive, but sometimes they undervalue the ability of primary school children to work autonomously on their research projects. Instead, the parents choose to complete a research project for their children by leaving no chance for the children to engage in a meaningful research activity. The other obstacle that prevents teachers' engagement with research is their previous schooling experience (belief in authoritarian power and abstract knowledge). In teacher training seminars the teachers often express their willingness to hear ready made recipes offered by the scholars rather than design their own methodologies or 
adjust the existing ones in a creative way. This is another obstacle that prevents teachers from doing research. Group interviews with teachers highlighted some reasons why the teachers prefer readymade knowledge: a lack of information in a field of their work, a school environment that does not support teachers' research activities, parental control over curriculum and content delivery, lack of self-confidence regarding the efficiency of their initiatives.

A considerable amount of literature (Eisner, 1994; Elliott, 1993; Freire, 1972) supports these reasons as low teachers' involvement in changing educational praxis. One such obstacle is the long tradition of authoritarian teaching in which evaluation is based mainly on testing and pre-packaged curricular materials, which impedes creativity, teachers' autonomy and self-confidence. Teachers' fears are grounded in the traditional academic model of teaching in which the primary role of the teacher was to teach and for the students to learn. Several studies have demonstrated a number of benefits of teachers' research: improvement of learners' performance, more possibilities for a dialogue about their learning, innovative instructional approaches to a more objective analysis of results (Langerstock, 2000; Welch \& Chisholm, 1994).

The benefits of teachers' engagement in research are evident: both students and teachers feel a greater sense of self-worth and self-confidence. Those few teachers who regain their voice are active interpreters and negotiators involved in an existing process of cultural construction and educational reconceptualization. Such teachers become agents of change not only in their own classrooms, but also reshape their schools in democratic ways. As several authors (Etherington, 2006; Kagan, 1992) suggest, teachers' engagement in doing research creates authentic and context-bound knowledge and promotes the generation of new knowledge. The research data indicate an evident correlation between the teachers' ability to organize research activity and the teachers' ability to motivate pupils' research in a more effective way. The study underlines a significant correlation between the teachers' research competency and openness to imagination and creative insights brought by children.

\section{Conclusions}

Inquiry is an integrated approach to teaching and learning, resulting in exploring issues in depth, raising questions for investigation and taking action for a sustainable future. Inquiry allows teachers to participate more actively in decision-making process and, consequently, to regain their voice. Teacher's voice is a crucial aspect of teacher initiated research and should lead towards improving educational praxis. This allows teachers to tie their classroom activities to profound pedagogical, social and philosophical purposes. Teachers identify the inadequacies of their conceptual frames of reference and become critical thinkers, which enables them to change their educational practice.

Teachers' engagement in research challenges the undemocratic, scientific and rational act of teaching. By becoming critical researchers, teachers begin to construct their professional lives by asking meaningful questions. In order to reevaluate their practice, teachers seek guidance from their frames of reference, as well from their authority (Schon, 1987; Kincheloe, 2003). Thus, teachers become active interpreters and negotiators of their experience involved in the educational reconceptualization.

The issue of teachers becoming researchers centres around the issue of motivation both intial motivation to get involved in research and also ongoing motivation throughout 
the whole research process; support both professional and personal, as well as expertise, time and opportunities for professional growth. As soon as teachers begin to incorporate elements of research in their work, they arrive at a better understanding of what is happening in the classroom. As the study suggests, if teachers hold power to reconstruct their own practice, then they are capable of reinterpreting the situation towards a more sustainable future.

The highest motivation for doing one's own educational research was among older teachers, while the lowest motivation was among younger teachers. The younger teachers consider themselves confident and equipped with the latest knowledge after graduating from higher education establishments. The main motivation why they engage in educational research is pressure from the administration. Their personal motivation for doing educational research is quite low). On the contrary, the main motivation for the older teachers is their personal growth.

The main obstacles that prevent a teacher from doing research and encouraging children in doing research are the following: a lack of sufficient time for the research, rigid state requirements preventing teachers from practicing creativity, overloaded schedule and a disbelief in their power to make a difference. Among the other factors mentioned by the teachers are high labour demands, reality of full time teaching, teachers' previous schooling experience and a belief in authoritarian power. Despite a number of obstacles, the teachers also see the benefits of doing research themselves and together with children. The benefits are numerous: a greater sense of self-worth and self-confidence, belief in one's power to make changes. This increases the teachers' motivation to carry out research and their capability of motivating pupils' research in a more effective way.

The research data indicates that the teacher-researcher issue refers to issues of teachers' empowerment. Therefore, in teacher training programmes more attention should be paid to factors that stimulate teachers to work with their feeling and thoughts, by encouraging them to believe in their authority and to act upon their decisions. Teachers should be empowered to reflect not only on their actions, but also on thoughts, feelings and ideas. Schools need to offer the culture of the research and to support teachers' initiative to make changes in their classrooms.

Teacher-initiated research may not offer solutions to teachers' problems, but it can provoke more in-depth about educational problems. Greater familiarity with the process of research in teacher training programmes is likely to promote greater comfort with research in general, particularly if teachers are encouraged to explore their own interests throughout their careers.

\section{References:}

Apple, M. (1999). Power, meaning and identity: Essays in critical educational studies. New York: Peter Lang.

Brookfield, S. D. (1995). Becoming a critically reflective teacher. SanFrancisco: JosseyBass.

Bruner, J. (1992). The narrative construction of reality. Critical Inquiry, 18(1), 1-21. Chattin-McNichols, J., \& Loeffler, M. (1989). Teachers as researchers: The first cycle of the teachers' research network. Young Children, 44(5), 20-27.

Cochran-Smith, M., \& Lytle, S. (1993). Research on teaching and teacher research: The issues that divide. Inside/outside: Teacher research and knowledge. New York: Longman. 
Dewey, J. (1916). Democracy and education. New York: The Free Press.

Eisner, E. (1994). The educational imagination: On the design and evaluation of school programs (3rd ed.). New York: Macmillan College Publishing.

Elliott, J. (1993). Reconstructing teacher education. London: Falmer Press.

Etherington, K. (2006). Becoming a reflective researcher. Using ourselves in research. London and Philadelphia: Jessica Kingsley Publisher.

Freire, P. (1972). Cultural action for freedom. Harmondsworth: Penguin.

Goswami, D., \& Stillman, P. (1987). Reclaiming the classroom: Teacher research as agency for change. Portsmouth: Boynton Cook.

Grišane, O. (2007). Organization of environment for the development of research skills in secondary school. In A. Pipere (Ed.), Education and Sustainable Development: First Steps toward Changes (Vol. 2, pp. 222-240). Daugavpils: Daugavpils University Academic Press "Saule".

Hargreaves, A. (1995). Revisiting voice. Educational Researcher, 25, 12-19.

Harris, K. R., \& Graham, S. (1994). Special issue: Constructivism: Principles, paradigms, and integration. The Journal of Special Education, 28, 233-247.

Husserl, E. (1970). The crisis of European sciences and transcendental phenomenology. An introduction to phenomenological philosophy. Trans. David Carr Evanston, Illusiana: Northwestern University Press.

Iliško, Dz., \& Kravale, M. (2007). Adult learners as researchers in master program in pedagogy at Daugavpils University. Acta Pericemonologica. Proceedings of the $5^{\text {th }}$ international JTET conference on theories and practices for education of sustainable development. Debrecen: University of Debrecen.

Kagan, D. M. (1992). Professional growth among pre-service and beginning teachers. Review of Educational Research, 62(2), 129-169.

Kincheloe, J. L. (2003). Teachers as researchers. Qualitative inquiry as a path to empowerment. London and New York: Routledge, Taylor and Francis Group.

Koutselini, M. (2008). Participatory teacher development at schools: processes and issues. Action Research. Retrieved October 14, 2008, from http://arj.sagepub.com/cgi/ content/abstract/6/1/29.

Langerstock, N. (2000). A passion for action research. Teaching Exceptional Children, 33(2), 26-34.

Linn, M. (1987). The new trust in science education research - establishing a research base for science education: Challenges, trends, recommendations. Journal of Research in Science Teaching, 24, 191-216.

Lytle, S. L., \& Cochran-Smith, M. (1992). Teacher research as a way of knowing. Harvard Educational Review, 62, 447-474.

McFearland, K. P., \& Stansell, J. C. (1993). Historical perspectives. In C. M. Patterson, K. G. Santa, A. Short, \& K. Smith (Eds.), Teachers as researchers: Reflection and action (pp. 12-18). Newark: International Reading Association.

Montuori, A. (2008). The joy of inquiry. Journal of Transformative Education, 6(1), 826. Retrieved October 14, 2008, from http://jtd.sagepub.com/cgi/content/abstract/ 6/1/8/.

Ochberg, R. L. (1994). Life stories and storied lives. In A. Lieblich (Ed.), Exploring identity and gender: The narrative study of lives. Thousand Oaks, CA: Sage.

Pipere, A. (2007). Becoming a researcher: Interplay of identity and sustainability. In A. Pipere (Ed.), Education and Sustainable Development: First Steps toward Changes (Vol. 2, pp. 241-263). Daugavpils: Daugavpils University Academic Press "Saule”. 
Sagor, R. (2000). Guiding school improvements with action research. Virginia: ASCD. Schon, D. (1983). The reflective practitioner: How professionals think in action. New York: Basic Books.

Schon, D. (1987). Educating the reflective practitioner. San Francisco: Jossey-Bass.

Schwandt, T. A. (2001). Dictionary of qualitative inquiry ( $2^{\text {nd }}$ ed.). Thousand Oaks, CA: Sage.

Stenhouse, L. (1981). What counts as research. British Journal of Educational Studies, 29(2), 103-114.

Stringer, E. T. (Ed.). (1999). Action research. Thousand Oaks, CA: Sage.

Welch, M., \& Chisholm, K. (1994). Action research as a tool for preparing specialists to use strategies - interventions in educational partnership. Teacher Education and Special Education, 17, 268-279.

\section{Correspondence:}

Dr Dzintra Iliško, Institute of Sustainable Education, Faculty of Education and Management, Daugavpils University, Parades 1, Daugavpils, LV-5401, Latvia. Email: dzintra.ilisko@du.lv 